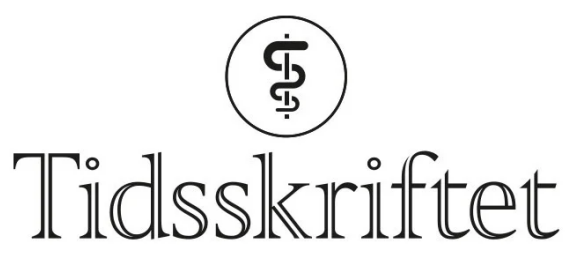

DEN NORSKE LEGEFORENING

\title{
Leukemia cutis
}

\author{
MEDISINEN I BILDER
}

\section{HELENE DAAE-QVALE HOLMEMO}

Seksjon for blodsjukdommar

Haukeland universitetssjukehus

Helene Daae-Qvale Holmemo er lege i spesialisering i indremedisin og i blodsykdommer.

Forfatteren har fylt ut ICMJE-skjemaet og oppgir ingen interessekonflikter.

\section{HÅKON REIKVAM}

hakon.reikvam@uib.no

Klinisk Institutt 2

Universitetet i Bergen

og

Seksjon for blodsjukdommar

Haukeland universitetssjukehus

Håkon Reikvam er spesialist i indremedisin og i blodsykdommer, er professor og overlege.

Forfatteren har fylt ut ICMJE-skjemaet og oppgir ingen interessekonflikter.

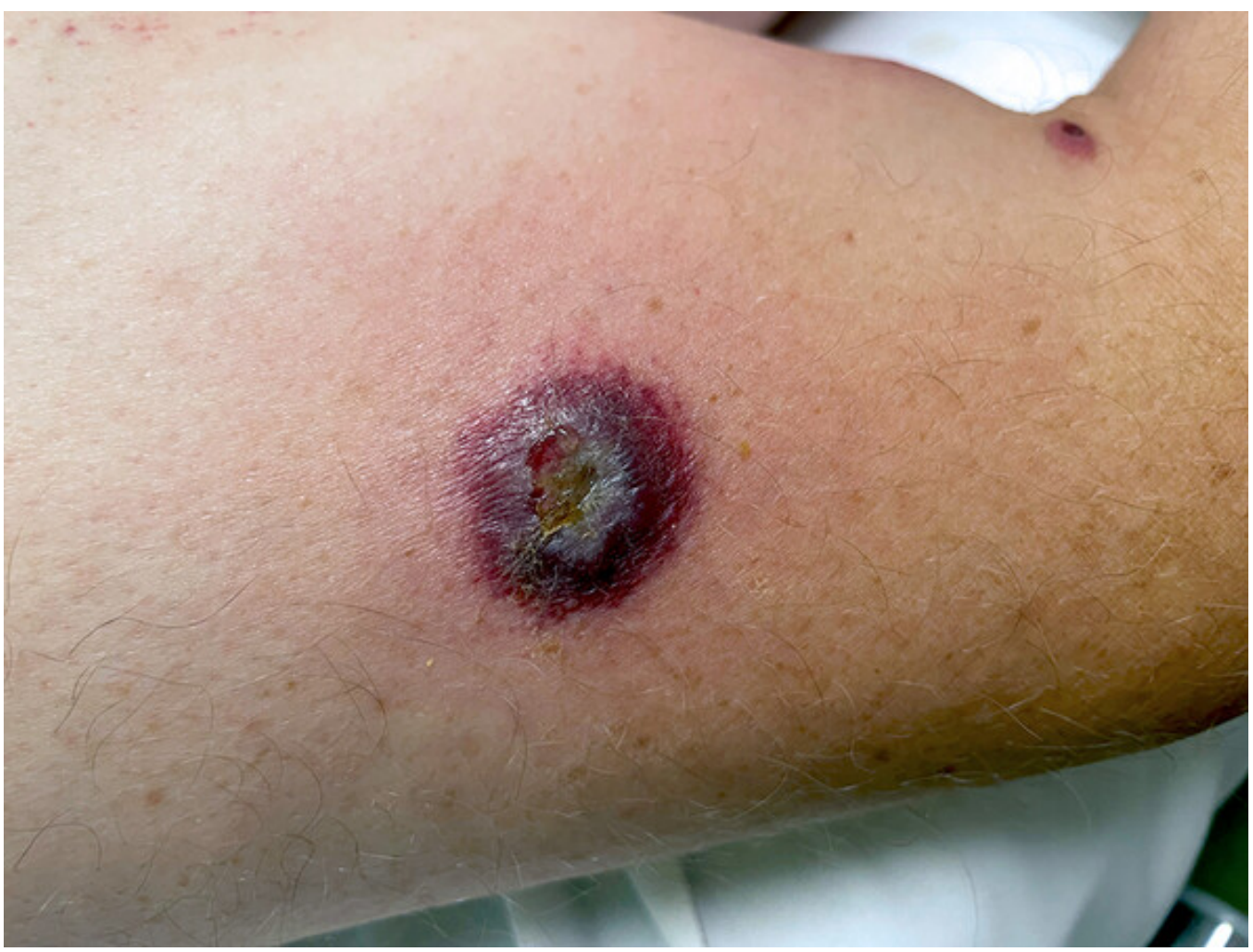


Bildet viser leukemiske hudinfiltrasjoner hos en mann i 50 -årene diagnostisert med akutt myelogen leukemi. Pasienten ble overført fra lokalsykehus til hematologisk avdeling ved universitetssykehus, der han ble innlagt med spørsmål om alvorlig infeksjon. Han hadde da 14 dagers sykehistorie med tiltakende luftveissymptomer, økende dyspné og fallerende allmenntilstand. De siste fire dagene var det også tilkommet flere flekkvise, nodulære hudlesjoner, mest uttalt på hals, bryst og overekstremiteter. Blodprøver ved ankomst universitetssykehuset viste hemoglobin 8,1 g/dL (referanseområde 13,4-17,0), leukocytter 122 $\times 10^{9} / \mathrm{L}\left(3,5^{-11,0}\right)$, trombocytter $60 \times 10^{9} / \mathrm{L}\left(145^{-348)}\right), \mathrm{CRP} 187 \mathrm{mg} / \mathrm{L}(<5)$ og laktatdehydrogenase (LD) $989 \mathrm{U} / \mathrm{L}(105-205)$.

Hudlesjonene hadde noe heterogent utseende og størrelse, men flere hadde en sentral oppfylling med mer inflammert aktiv randsone. Bildet viser et større element fra lateral side av høyre overekstremitet, som ble biopsert. Ytterligere utredning verifiserte diagnosen akutt myelogen leukemi med undergruppe akutt monoblastleukemi. Grunnet hyperleukocytose ble det oppfattet som kritisk å raskt initiere kjemoterapibehandling. Denne ble startet dagen etter innkomst. Etter få dager falt leukocyttallet betydelig, samtidig som hudforandringene raskt gikk i regress. Svar på hudbiopsien verifiserte tilstedeværelse av leukemiske blastceller i alle lag i dermis, forenlig med leukemisk infiltrasjon i hud.

Leukemia cutis er definert som infiltrasjon av neoplastiske hematopoetiske celler, enten myeloide eller lymfoide, som resulterer i klinisk identifiserbare kutane lesjoner (1ㅁ). Det kan i prinsippet oppstå ved alle typer leukemier (11), men undergruppen akutt monoblastleukemi, ofte med samtidig uttalt leukocytose, er den hyppigst forekommende. Denne leukemiformen synes å være betydelig invasiv og kan ofte føre til ekstramedullær sykdom, som kan manifestere seg i ulike organsystemer, oftest i tannkjøttet, gastrointestinalkanalen eller huden. Akutt leukemi med høye leukocyttall $\left(>100 \times 10^{9} / \mathrm{L}\right)$ må sees som en medisinsk akutt tilstand der det haster å starte med behandling (므). Man må også være oppmerksom på at pasienter med akutt leukemi er immunkompromitterte, og alvorlige infeksjoner som også kan manifestere seg ved hudlesjoner, er en viktig differensialdiagnose (3).

Pasienten har gitt samtykke til at artikkelen blir publisert.

Artikkelen er fagfellevurdert.

\section{LITTERATUR}

1. Cho-Vega JH, Medeiros LJ, Prieto VG et al. Leukemia cutis. Am J Clin Pathol 2008; 129: 130-42. [PubMed][CrossRef]

2. Akkök CA, Bergrem A, Tangen JM. Hyperleukocytosis. Tidsskr Nor Legeforen 2014; 134: 1365. [PubMed][CrossRef]

3. Tvedt TH, Orstad S, Skrede S. Svarte blemmer i huden og Enterobacter i blodet. Tidsskr Nor Legeforen 2015; 135: 1454. [PubMed][CrossRef]

Publisert: 22. desember 2021. Tidsskr Nor Legeforen. DOI: 10.4045/tidsskr.21.0695

Mottatt 2.10.2021, første revisjon innsendt 6.11.2021, godkjent 16.11.2021.

(C) Tidsskrift for Den norske legeforening 2023. Lastet ned fra tidsskriftet.no 26. april 2023. 